\title{
Mathematical Instruments Commonly Used among the Ottomans
}

\author{
Irem Aslan Seyhan \\ Department of Philosophy, Bartın University, Bartın, Turkey \\ Email: iaseyhan@bartin.edu.tr
}

How to cite this paper: Seyhan, I. A. (2019). Mathematical Instruments Commonly Used among the Ottomans. Advances in Historical Studies, 8, 36-57. https://doi.org/10.4236/ahs.2019.81003

Received: January 24, 2019

Accepted: March 5, 2019

Published: March 8, 2019

Copyright $\odot 2019$ by author(s) and Scientific Research Publishing Inc. This work is licensed under the Creative Commons Attribution International License (CC BY 4.0).

http://creativecommons.org/licenses/by/4.0/

(c) (i) Open Access

\begin{abstract}
At the end of 17th century and during 18th century, after devastating Russian wars the Ottomans realized that they fell behind of the war technology of the Western militaries. In order to catch up with their Western rivals, they decided that they had to reform their education systems. For that they sent several students to abroad for education and started to translate Western books. They established Western style military academies of engineering. They also invited foreign teachers in order to give education in these institutes and they consulted them while there were preparing the curriculum. For all these, during the modernization period, the reform (nizâm-1 cedid) planers modelled mainly France, especially for teaching the applied disciplines. Since their main aim was to grasp the technology of the West, their interest focused on the applied part of sciences and mathematics. For that reason, they had a very keen interest on mathematical instruments. The main objective in this article is to examine mathematical instruments commonly used in the Ottoman empire. We examined that by dividing the subject in two periods: The Classical period (Medieval Islamic Echole) and the Modernization period (Western Echole). Our main focus in this article will be the Modernization period and the instruments used in the Ottoman military academies.
\end{abstract}

\section{Keywords}

Mathematical Instruments, Ottoman Mathematics, Ottoman Military Engineering Academies, Military Engineering Academies, Compendium of Mathematical Sciences, Chief Instructor Ishaq Efendi

\section{Introduction}

The Ottomans are notorious with their combatant nature during the history. However, when the time changed and sword craft left its place to the war technology supported by engineering, they fell way behind of their time and that na- 
turally led them to an inevitable result of defeat in several wars around the 18th century. After these devastating wars, especially after the unprosperous Russian wars, they realized a needed reform especially in the military and they started to seek urgent solutions. They also realized that in order to catch up with their Western rivals in the battlefield, they should have reformed their education system. Therefore, they established Western style military academies of engineering. They opened the Navy Military Engineering Academy (Mühendishâne-i Bahri Hümayun) in 1776 and Army Military Engineering Academy (Mühendishâne-i Berr-i Hümayun) in 1795 in order to compensate the deficiency of cognition of the empire and transferred Western knowledge and technology related to navy and military. Upon taking a glance to the other countries' corresponding military academies and compare the establishment dates, we see the Ottomans were not too late to join that military engineering academy trend. First of such kind of academies was Accademia Militare di Modena (1678) in Turin Italy then St. Petersburg Artillery Military Academy (1717) founded in Russia. Woolwich Royal Military Academy (1741) was opened in England. Ecole Militaire (1750) was founded in Paris. As a revised continue of that academy in 1777 Comte de Saint Germain Ecole des Cadets was opened and eventually in 1876 Ecole Superieure de Guerre was established. Last but not the least Theresianische Militär Akademie (1751) was set up in Austria. In later years, Preussische Kriegsakademie (1801) and West Point Military Academy (1802, USA) were established.

However, the modernization of the education system was not successful and fully functioning of the revised curriculum was only possible in the second half of the 19th century. That was mainly because of the traditional teachers, who did not want to leave the scholastic madrasa education system even in the 19th century. Although the curriculum was revised they were continuing to stall the young cadets by teaching out of circulation lessons. Of course, such teachers couldn't stop the modernization period. First of all, there were second type of teachers who were advocating the modernization. They were translating from Western sources and preparing compendiums for students. Secondly, once the Ottomans realized that they fell behind their rivals, they did their best to catch up with them and their policy on education did not change in spite of the abolition of novus ordo seculorum (nizam-1 cedid) and rebellion of the reactionary in 1807 and murder of Selim the 3rd.

In 1827, in order to compensate the need of well-educated doctors and surgeons for military, the Imperial Medical School (Tiphane-i Amire) was established. In 1834 Military General Stuff School (Erkan-1 Harbiye Mektebi) and 1838 another Imperial Medical School (Mekteb-i Tibbî-i Adlî-i Şahane) were opened. In 1883, College of Geometry for civil servants (Hendese-i Mülkiye) was opened by imitating the Ecole National des Ponts et Chaussees. Therefore, positive sciences by means of modern sense of science, entered the even to the secondary and high school educations (Adivar, 1970: pp. 197-198). In order to train civilian doctors in 1867 another Medical School of Civil Service (Tibbiye-i Mülkiye) was 
opened.

The intellectual progress of the Ottomans was under two different ecole. These were:

1) Medieval Islamic Science \& Technology Ecole (or Eastern Ecole) (14th 18th century). Classical Period.

2) Western Science \& Technology Ecole (18th - 20th century). Modernization Period.

I have already mentioned partly about the Western Science \& Technology Ecole (Modernization Period) above.

Medieval Islamic Science \& Technology Ecole started with the establishment of the first madrasas in the empire in the 14th century and lastedtill the mid 18th century's Ottoman Russian wars. In this period, the works of Medieval Islamic scholars such as Thābit ibn Qurra al-Ḥarrānī (AD826-AD901), Hasan Ibn al-Haytham (965-1040), Omar Khayyâm (1048-1131), Nasir al-Din Tusi (1201-1274) were preserved, taught and widely studied around the empire. The mentioned works of Islamic scholars were known under a general name "mutavassitat" among the Ottoman scholars. Those were mainly the Arabic translations and commentaries of well-known ancient Greek scholars' works such as Euclid, Archimedes and Ptolemy. We also are going to witness that the instruments which were commonly used in the classical period were the instruments inherited from Medieval Islamic World. Therefore, our main focus in this article will be the modernization period and the instruments used in the Military Engineering Academies and their curriculum on mathematics since they were the first modern style academies in the empire. Also, the geometric instruments mentioned in Chief instructor Ishaq Efendi's (1748-1834) Compendium of Mathematical Sciences mentioned briefly in this article. Meanwhile the obscure Ottoman terminology about the name of the mathematical instruments tried to be revealed.

\section{Instruments Used in the Classical Period}

"Mutavassitat" works were very popular before the modernization period. The mentioned books about astronomy and mathematics were reproduced systematically in Istanbul as a will of the Sultan Mehmed the Conqueror (1432-1481) for the first time. During the impact of the Eastern Ecole, mathematics and geometry were taught in madrasas systematically from these "mutavassitat" sources. The most widespread text books were Kadizade er-Rûmî's commentary on Şemsüddin es-Semerkandî’s Eşkâll-i Te’sîs and Nasir al-Din Tûsîs Tahrîru Kitabi Uklidis (An Essay on Euclid's Elements). Geometry was especially an important discipline for the Ottomans, since it was crucial for solving the problems on inheritance of the land.

The Ottomans also followed the Islamic tradition on the instrument making. In this period, mathematics and astronomy were especially important for them to solve three main problems about: 
1) Estimating the prayer time precisely.

2) Finding the direction of qibla (the direction of Mecca).

3) Navigation on the sea and land.

4) In architecture and ornamenting.

Therefore, they preferred to use instruments which were helping them to solve these problems.

In that period, their main motivation for science was mainly based on religious needs as well as daily practical needs like calendar making, time keeping, inheritance problems etc. However, in the second period (modernization period) the main interest was military needs. In order to estimate the prayer time and determining the direction of Mecca they were using qibla compasses between $17^{\text {th }}$ and $19^{\text {th }}$ century (see Figure $1 \&$ Figure 2 ).

One of the most widely used instrument was astrolabe in the Classical Period (Figure 3). Astrolabe is a very complicated device that allows various calculations about the altitude of the stars and celestial objects. It is an elaborate inclinometer that enables astronomers to calculate the position of the Sun and prominent stars with respect to both the horizon and the meridian. It includes plane image of the celestial sphere and the principal circles as well as an alidade on the back surface of it in order to target the celestial objects. Ottomans used this device until the beginning of 20 th $\mathrm{c}$.

Another widely used instrument-not only in Ottomans but also in the all Medieval Islamic World-was the quadrant (rubû) (Figure 4). They had two

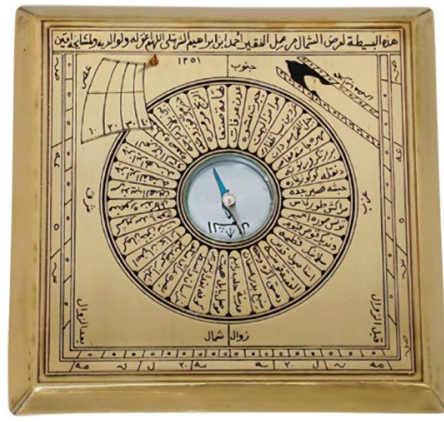

Prayer Compass

Replica of a I9th c. Ottoman-Turkish compass. The original is in the RautenstrauchJoest-Museum at Cologne.

$$
\text { (Cat. III, 77; C I.I8c) }
$$

Figure 1. 19th century Ottoman compass in order to estimate qibla direction and prayer time. The original of that compass is now in Rautenstrauch Joest Museum für Völkerkunde Museum in Cologne. This compass was made by Ahmed b. Ibrahim es-Serbetli in 1853. The names and coordinates of the important capitals of Islamic world have been carved in the plate around the center of the compass. There is a compass needle that stands in the center. Compass works in these capitals. One can determine the direction for prayer towards Mecca with the compass. In addition to that with the help of the gnomon on the side indicated as west, the times of prayers can be read off from the scale adjacent to it (Sezgin, 2010: Vol III, p. 77). 


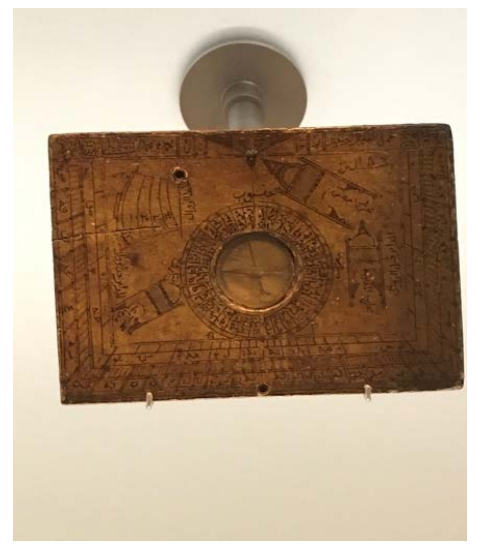

Figure $2.17^{\text {th }}$ c. Ottoman qibla estimating compass (Paris, Musee IMA ${ }^{1}$ inv. Al 85-05).

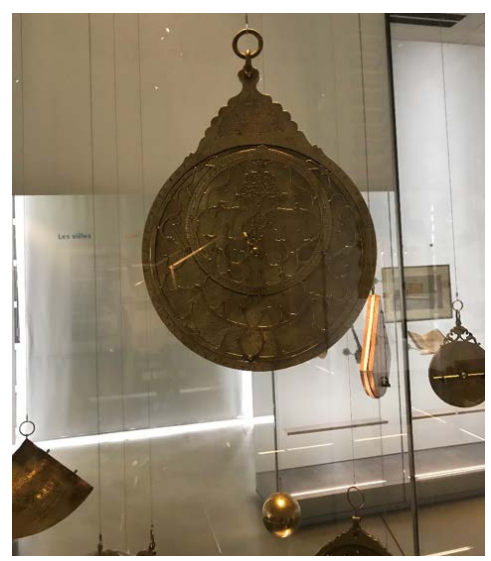

Figure 3. Astrolabe (Paris, Musee IMA).

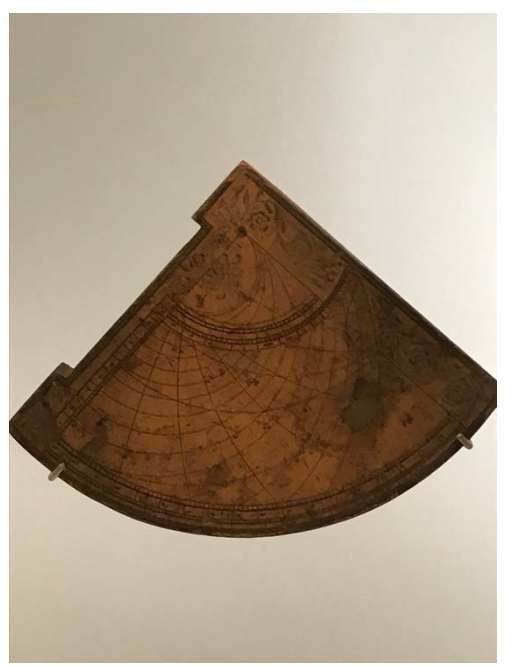

Figure 4. Ottoman, 17th c. Astrolabe Quadrant (Musee IMA inv. Al 84-08). Assume that an observer stands on the south pole and there exists a tangent plane in the north pole, the $1 / 4$ th of the conical projection of the sky to that mentioned plane called Astrolabe Quadrant. That device is widely used for astronomical calculations and time keeping until the beginning of 20th century. It also calculates longitude of Sun.

${ }^{1} I M A$ used as the abbreviated form of Institut du Monde Arabe in this article. All the pictures from that museum are taken by the author herself. 
main types of quadrants. One of them was used in observatories and it was pretty big and named as libne. Libne is a wall quadrant used by Islam astronomers in order to calculate the altitude of the stars and to observe the meridian transition of the stars. It was also used in order to designate the latitudes and measure the slope of the ecliptic (Unat, 2001: p. 124). The other type of the quadrants was called as rubu tahtası (quadrant board). Quadrant board was a portable calculating device derived from libne. In general, it was used to make calculations based on the height of the Sun and other celestial bodies. It was also used to measure the depth of the wells, the height of the towers and mountains and the width of the creeks (Ziya, 1338: pp. 126-127). Another utility of it was to calculate the solutions of the trigonometric functions such as sine and cosine. Therefore, it was used as ananalogue computing device among Ottomans till 20th century. Such kind of quadrants were called as rubû'el-müceyyeb (known as sine quadrant). Each arm (radii) has a scale related with sine and cosine. These kinds were mainly so designed to solve the mathematical relations based on geometric proportions. We are going to mention about such quadrants more in detail in the 3rd chapter of our article since these instruments were used till the 20th century. We also have to mention them in modernization period.

In addition to these instruments which allow them to compensate their navigational and religious needs, they were of course using various measuring devices such as levelling instruments, scales and protractors etc. All these instruments can be found in Sezgin's catalogue. Therefore, we will not mention about them here and forge a head to the modernization period (Figures 5-7).

\section{Instruments Used in the Military Engineering Academies (Modernization Period)}

As we mention above, military engineering academies were founded in order to

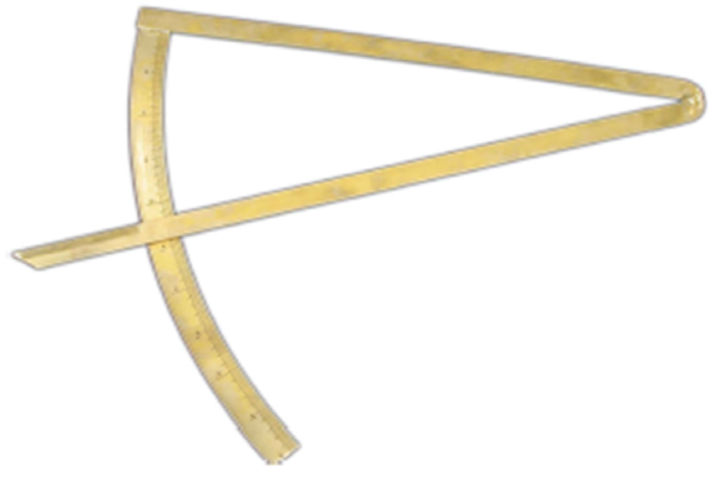

Protractor

This type of protractor is to be found among the tools of Ottoman astronimers shown in a miniature from the 16th century.

(Cat. III, 156; D 1.16)

Figure 5. Protractor (Sezgin, Vol III, p. 156). 


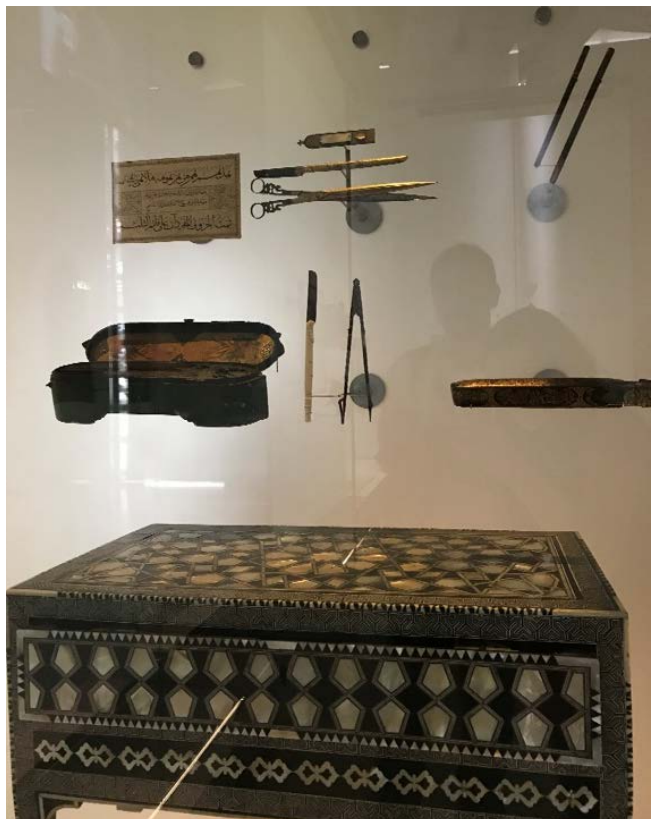

Figure 6. Ottoman engineer toolbox (Istuc) (IMA). Classical Period.

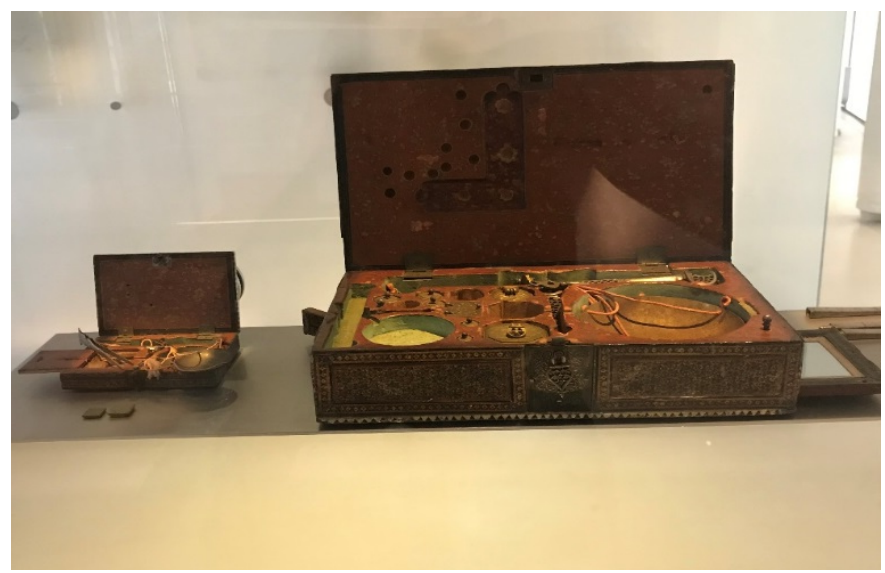

Figure 7. Ottoman compass, scale set (IMA). Classical period.

modernise the education mainly and to support the modernization of the Ottoman army. In any way, they were the first modern education institutes founded in the empire. Therefore, the mathematical instruments used in such academies demonstrate us the level of Ottomans in mathematics, astronomy and also in engineering in the modernization period. I believe the following list will also reveal why the Ottoman modernization was not successful. Here, the list of mathematical instruments used in the military engineering academies of the Ottomans (combined inventory list of tools and instruments of the years 1801, 1816, 1822, 1826 and 1836) will be presented (Beydilli, 1995: pp. 375-409). That combined list is including many instruments from the classical period, which raises a question in mind, why would they be used such obsolete instruments such as astrolabe, camera obscure etc. while the main intention was to reform their education system and scientific thought. 
There were no pictures or explanations in these original documents (inventory lists). The original of these instruments are not exhibited anywhere cumulatively. Therefore, in order to identify these instruments, we only can use dictionaries and museum catalogues and made reasonable guesses about the identification of these instruments.

1) Hedefeli sagir mesaha tabilesi: Targeted small surveying table. Used for fast method of surveying, most probably for military reasons.

2) Dürbünlü plançeta mastaras: Surveyors plane table with alidade and binoculars. Used for surveying in military.

3) Çifte dürbünlü alet-i irtifa-yı arazi: Double binocular instrument which measures height of the field. (Most probably a double theodolite or double theodolite pibal which is a precision instrument for measuring the angles for advance surveying). Used for martial reasons.

4) Tam daire şeklinde mesaha tabilesi: Circle shaped surveying/measuring tray. (Most probably a protractor or might be a sea astrolabe). (?).

5) NIsf-1 daire şeklinde mesaha tabilesi: Semicircle shaped surveying/measuring tray. A protractor used for measuring the angles, most probably in degrees.

Chief instructor Ishaq Efendi (1748-1834), who was very eminent figure in the history of military academies of the Ottomans by being a vigorous advocate of modernization, also mentions about this instrument in his compendium Mecmûa-i Ulûm-i Riyaziye, Vol. 1 (p. 397) with a name of "Manqala" or "Tabila" (Figure 8).

Ishaq Efendi was born in Narta (in Janina) (today it is in Greece's border). $\mathrm{He}$ was a Jewish converted to Islam. He played a crucial part about transmitting the modern sciences to the Ottomans by the help of his major work Mecmua-i Ulûm-ı Riyâziye. He was able to speak many languages such as Arabic, Persian, Hebrew as well as Greek, Latin, and French. Mecmua-i Ulûm-ı Riyâziye is a four volumed "Compendium of Mathematical Sciences" published between 1831-34. It is a very reliable source on Ottoman science and considered as the introduction of the modern sciences to the empire. It was printed in Istanbul Bulak printing house. Ishaq Efendi used European sources such as Étienne Bézout's books while preparing this compendium. This work is accepted as the introduction of modern sciences (such as mathematics, physics, chemistry, biology, astronomy, mineralogy, botanic, and zoology) cumulatively to the Ottoman literature. It is also important by including the first Turkish article printed on modern chemistry as well as the analytical geometry. Among Ishaq Efendi's other works there are:

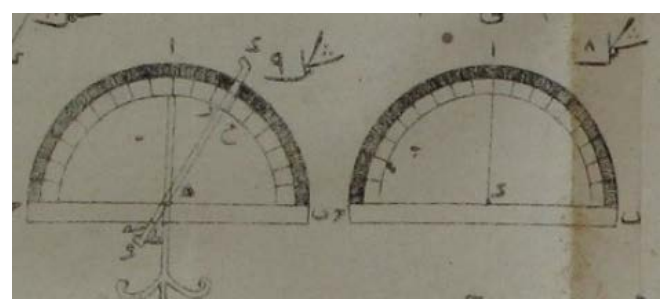

Figure 8. Manqala or Tabila (Protractor) in Ishaq Efendi (1257: p. 1 of his figures). 
Usûl-i İstihkâmât. Translation of French mathematician Guillaume Le Blond's (1704-1781) Eléments des Fortifications (Paris, 1739).

Aksǜ l-merâyâ fî ahzỉ z-zevâyâ: The three-parted opus contains information about the use of engineering tools (such as octant) for measuring the altitude and distance.

Kavâid-i Ressâmiyye: It is about the rules and application of the land surveying.

Risâle-i Ceyb: It is about the time estimation.

6) Çifte hedefeli rub-u daire: Double targeted quadrant. This instrument might have been used for military reasons, navigational purposes as well as astronomical calculations. Different types of quadrants could be used in order to calculate time of the day like a clock, longitude and latitude, altitude of stars including the Sun. We will be mentioning special types of quadrants more in detail below.

7) Sagir ve kebir mastara-1 muvazat: Small and big parallel rulers. Used mostly for technical drawing especially in navigation in order to draw parallel lines without any errors (Figure 9).

8) Akrebli daire-yi basita-yi afaki: Circle shaped sundial with gnomon which measures height (Basita: a) Sundial, sundial which measures height. b) Surface. Akreb: pot hook, double hook. Akrep: hour hand). (?). This device couldn't be identified it maybe a navigation device.

9) Mihver-i müteharriki ve hatt-1 saireli basite: A sundial (which measures height-maybe by using the height of shadow-) which has a moving axis and another line. (?).

10) Pusulalı hatt-1 istiva basitesi: An equator compass (Hatt-1 istiva: Equator). A compass probably used for navigation.

11) Satıh-1 müteharriki istilam içün çeküllü nısf-1 daire şeklinde terazi: Semicircle shaped balance with plumb line, in order to measure (mark) moving areas. (?).

12) Dürbünlü pusulalı ruhlu plançeta: Moveable surveyors plane table with binocular and compass. Device used in surveying, field drawing while drawing maps and charts. Also, can be used for surveying in military while determining the level and plainness of surface.

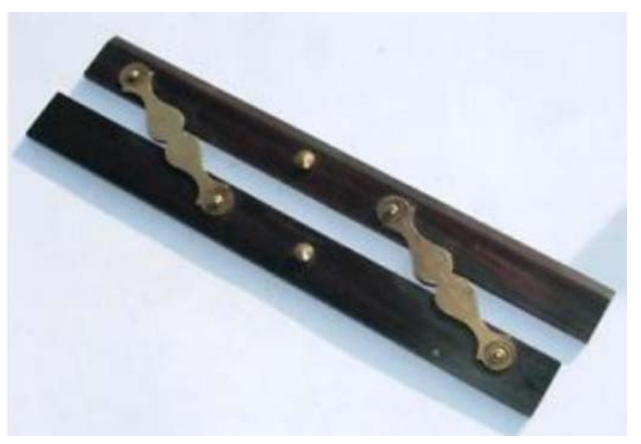

Figure 9. Parallel rulers. 
(Ruhlu: a) Having a soul or spirit, animated. b) Vivid. May be that phrase was used in order to describe automatically moving device, but there is no further proof of that. It can also be translated as "moveable").

13) Hedefeli ve ruhlu demir kollu tesviye terazisi: Levelling instrument which has a target and moveable iron handle. Used for levelling.

14) Sekstant tabir olunur dürbünlü alat-1 irtifaiye: Sextant is an instrument which has binoculars and measures the altitude. It is a double reflecting celestial navigational instrument. It is used for measuring the angle between an astronomical object and the horizon or the angle between any two visible objects. Estimation of this angle between the horizon and the particular astronomical object can be used in order to calculate the position line if we also know the local time. These position lines are essential for estimating navigator's location (Figure 10).

15) Usturlab-1 basite tabir olunur alat-1 hendesiye: Astrolabe. This instrument was one of the most sophisticated instrument of its time. It was discovered by ancient Greek scholars for astronomical, observational purposes and developed by medieval Islamic scholars especially for time keeping and navigational problems. These instruments were made for specific latitudes. Ottomans were using this device especially for solving religious based problems such as finding the direction of qibla and calculating the exact time for prayers. It was the most widely used astronomical device among Muslim scholars. It was used for measuring the ascendance and inclination of astronomical objects as well as tracking their appearance (Figure 11).

16) Çar-kuşe tabir olunur alat-1 hendesiye: (Çar-kuşe: Small triangle. Çar-guşe or Çarköşe: Quadrilateral, four cornered.) It is most probably a set square. It is used for solving geometry problems.

17) Sath-1 münharifi tesviye veyahud sath-1 müsteviyi sath-1 ufka muvazi vaz için ruh terazisi namıyla meşhur alet-i hendese: (?). Kind of a levelling instrument. It is used for levelling. The exact identification of this device is unclear.

18) Su terazisi: Water compass.

19) Humbara terazisi: Bombshell scale.

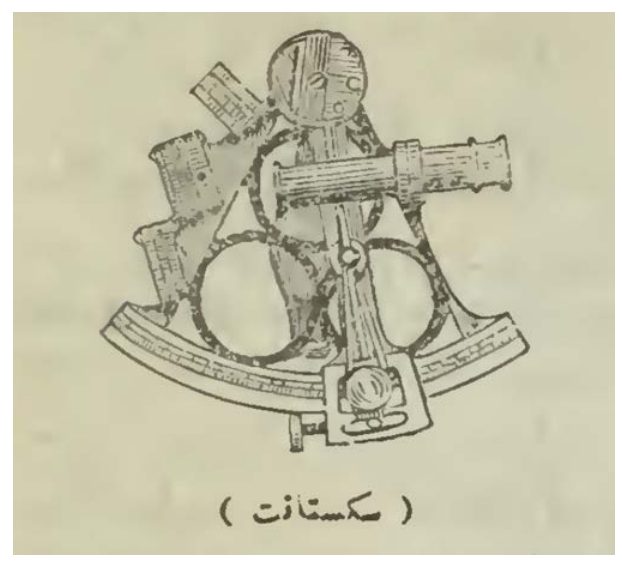

Figure 10. Sextant. 


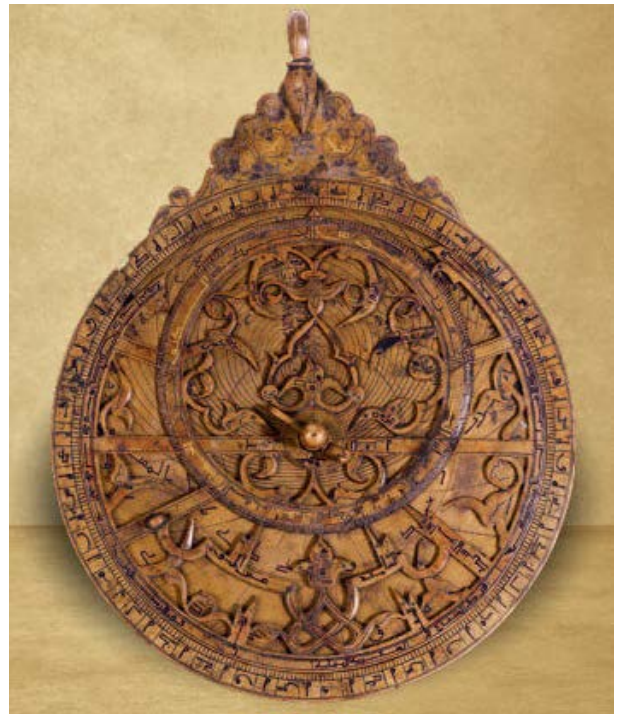

Figure 11. Ottoman astrolabe (15th AD), from the Catalogue of Museum for Islamic Art, Cairo.

20) İstuç. Engineer's toolbox.

21) Plançeta: Measuring table or ruler. Surveyors plane table. It is used for surveying in military.

22) Oktant: Octant. That arc shaped instrument was one eighth of the circle, it looks like sextant. It was also called as reflecting quadrant. Primary use of octant was in navigation.

23) Pergar-1 nisbe: Sector. This was a geometrical instrument used for solving all kinds of proportion based problems. It will be explicated below.

24) Zencir. Measuring Chain. It was used for measurements.

25) Iskala: Scale (Most probably scaled ruler).

26) Kamera uskure: Camera obscura. It was an optical amusement instrument also called as "the dark room". It allows to demonstrate the phenomenon that occurs when an image of a scene at the one side of the screen, which has small pin hole on it, is projected through that pin hole in another screen wall (standing parallel to pinned screen in a dark room) as a reversed and inverted image (Figure 12).

27) Rubu Tahtas: Quadrant board.

28) Küre-i Sema: Celestial Globes. These globes exposed apparent positions of the stars.

29) Nısf-1 daire şeklinde hedefeli pusulalı kar-ı kadim sehpası nakıs mesaha tabilass: (lit.) Semicircle shaped compass with a target. (?). Probably they were defining a clinometer which was used for surveying.

The above list of mathematical instruments was selected from the inventory lists of the Military Engineering Academies. They were titled as "tools and instruments" (alet, edevat) and they were sectioned as geometrical instruments (alat-1 hendesiye). In addition to these above instruments, all kinds of rulers, army and marine compasses and scales were also present in these inventory lists. 


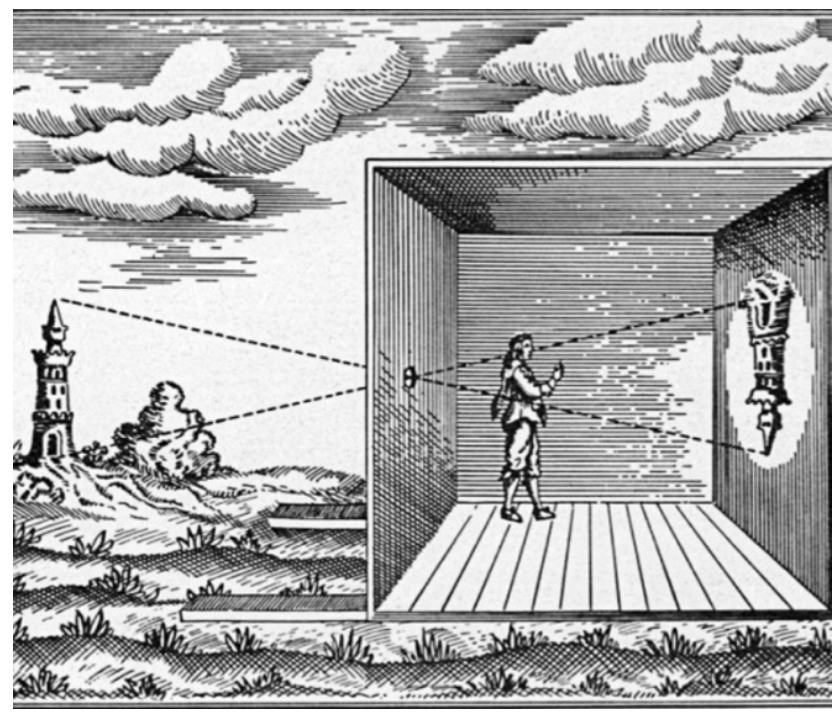

Figure 12. Camera obscura depiction of A. Kircher (Ars Magna, 17th century).

It seems that the Ottomans recorded all kinds of computing and surveying devices under the title of "geometrical instruments". It is indeed a common thing to use the nomenclature "mathematical instruments" for surveying devices and computing tools but, the Ottomans seem to have preferred using "geometry" term instead of "mathematics". Actually, that makes sense when we consider the fact that majority of their devices were used for geometrical and surveying problems. However, there is a thing that doesn't make that much sense; there was not any differentiation between the astronomical, physical or biological devices which indicate that the lines between the disciplines were obscure. That shows all these practical technical instruments were put in the same pot, from astrolabe and camera obscura to microscope, as well as several other engineering and military tools. There were also much more simple tools in these inventory lists such as needles, which also indicates that there was not any differentiation among the simple and complex instruments. They called every kind of practical instrument cumulatively as geometric instrument.

It is very hard and sometimes almost impossible to determine which instrument corresponds to which one by the modern terminology. The reason is that: The Ottomans neither created a proper terminology nor used a descriptive definition while listing their instruments. Also, there are no images or drawings in these inventory lists. Instead they used the nomenclatures as a definition itself. Simple devices are easy to guess by these nomenclatures. For instance, mastara-1 muvazat is definitely a parallel ruler. There is no doubt about it. However, the more the device gets complex, there is a less chance to identify it. Although in those cases the nomenclatures contain longer definitions, these definitions create nothing else but a confusion. They do not help while identifying these instruments. Such as in the example of (8) Akrebli daire-yi basita-yi afaki which means, "circle shaped sundial with gnomon which measures height". What exactly does that stand for? Akrep, is an hour hand with the literal translation and 
basita is sundial. In that case, Akrep should be used in order to state gnomon in this particular example. According to this literal translation, this sundial should be measuring the altitude, most probably by using the height of shadow. Yet that is nothing further than a reasoned guess. Another example is (9) Mihver müteharrikti ve hatt-1 saireli basite: "A sundial which measures height (maybe again by using the height of shadow) which has a moving axis and another line". That can be anything. That is why I have marked those instruments with "(?)" in the above list. These are the ones that I made a literal translation but, could not be certain about their identification.

In the examples of (12), (13) and also (17) we are seeing "spirited" (ruhlu) instruments which were very hard to identify. Ruhlu literally means having a soul or spirit, it also means vivid. Therefore, it was most probably been used in order to state the instruments which were moving partly. That phrase may also have been used to describe automatically moving device, but it is very unlikely.

Plançet or plançeta has different corresponding in different dictionaries. Ottoman-Turkish dictionaries defineit solely as a measuring device, while English-Ottoman dictionaries defineit as surveyors' plane table. In Chief instructor Ishaq Efendi's Mecmua-i Ulûm-1 Riyâziye Vol. II., he describes plançeta as a device which was useful for mapping a surface (planary sketching) and sketching faraway places by downscaling them (pp. 67-69). He mentions this device in his VIIth article of Vol. II which is about geometric operations in chapter 3-Planary sketching. Ishaq Efendi's definition also sustains that, instrument was surveyors' plane table. In the same article, he also defines levelling art as, "Locations which have equal distance from the centre of the Earth called on the same plane or on the same surface, equality or difference of these distances are the interest of the levelling art". Additionally, he gave information about some levelling instruments (tesviye aletleri), linear measurement, geometric operations about fortification, surface and solid measurements (Figures 13-16).

As we mentioned in the previous chapter most popular instruments for the Ottomans between the 14th - 18th centuries, were quadrant and the astrolabe.

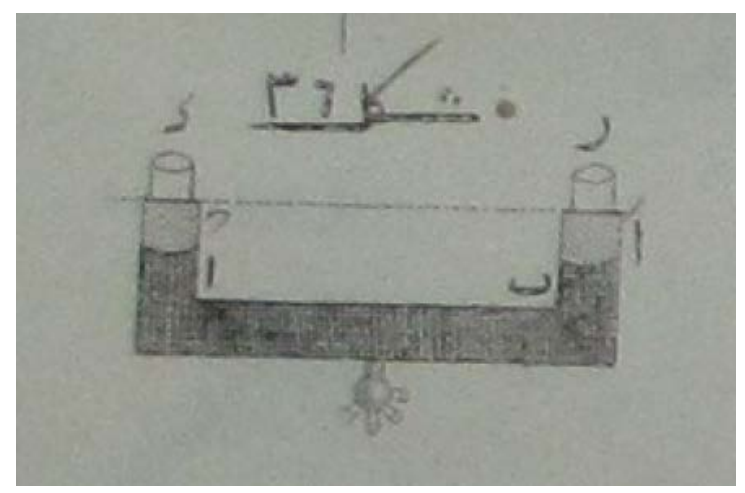

Figure 13. Measuring example from Ishaq Efendi, Vol. 2, picture 36, belongs to p. $60 .^{2}$ ${ }^{2}$ In his book like in many other historical books, shapes are given cumulatively at the end of the book. Therefore, in order to provide convenience to the interested readers I stated the pages where those pictures belong in the text. 


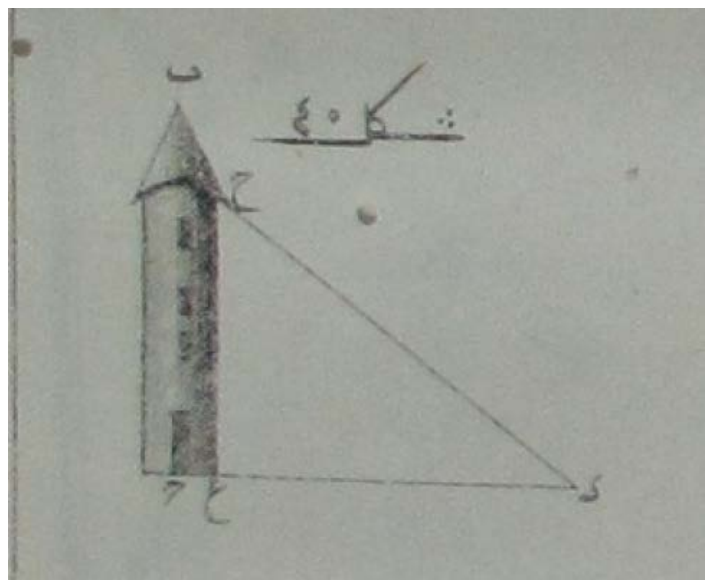

Figure 14. An example of measuring a height of fortress from Ishaq Efendi, Vol. 2, picture 40 belongs to p. 63 .

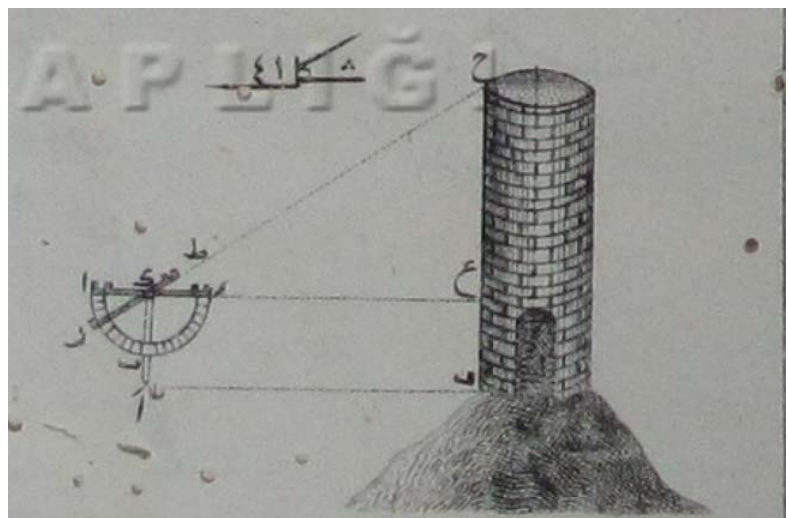

Figure 15. An example of measuring a height of door of the fortress with the help of a protractor from Ishaq Efendi, Vol. 2, picture 36, belongs to p. 63.

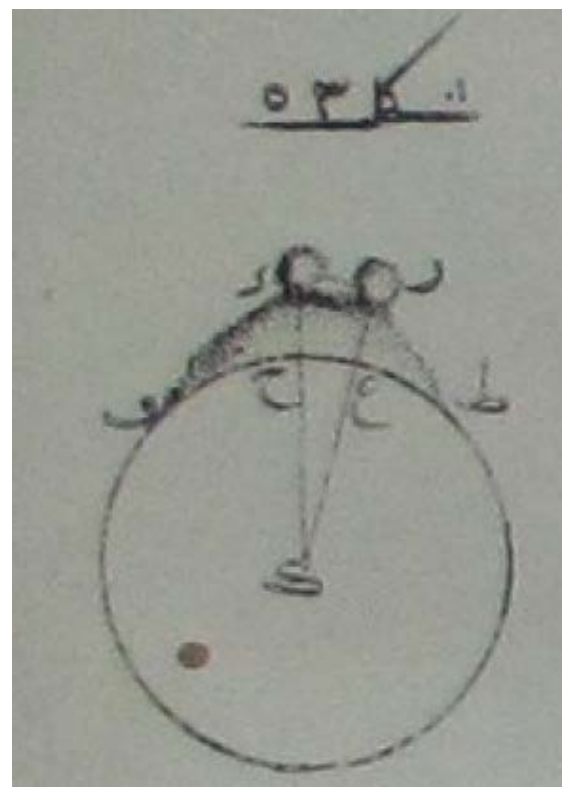

Figure 16. An example of measuring the distance between trees RD on the mountain TF from Ishaq Efendi, Vol. 2, picture 53, belongs to p. 76 . 
Quadrant board (rubu tahtasi) was of course much more popular than astrolabe since it was a less complicated device. Astrolabes were solely used by scholars while quadrants were used also by common people as a clock. Mostly common quadrants consisted of two faces: rubû̉ el-müceyyeb or rubû̉ el-düstûr (sine quadrant) and rubû el-mukantara (astrolabe-quadrant). Assume that an observer stands on the south pole and there exists a tangent plane on the north pole. The $1 / 4$ of the conical projection of the sky to that mentioned plane is called rubû̉ el-mukantara. It was used for astronomical calculations such as calculating the Sun's longitude. The other side namely rubû el-müceyyeb (sine quadrant) was used for trigonometric calculations. It has two perpendicular scales inserted to the radii of the quadrant. One of these scales is sine line and the other is cosine line, each of these lines degreed till $60^{\circ}$. There is a pendulum (el hayt) that stands in the centre-in the intersection of this lines-, and there is an adjustable indicator (el-muri) on it. There are further lines inserted on the quadrant which were all necessary for trigonometric calculations namely, first mid-afternoon (asr-1 evvel), second mid-afternoon (asr-1 sanii), trial line (hatt-1 imtihan), arc of sine (tecvîbü'l evvel), arc of cosine (tecvîbü’l sânî), big inclination arc (kavsü’l meyli'l azam) and altitude arc (kavs-i mutâli') (Figure 17) (Acar, Bir, \& Kaçar, 2014).

As far as Takîyuddîn ibn Ma'rûf (1521-1585) inform us in his treatise "The calculations which one can do with the help of rubûel-müceyyeb" (Rub'u'l-Müceyyeble Yapılan İşlemler Manzumesi, Süleymaniye library, H. Hüsnü Paşa Collection, nr.1135), it was widely utilized for:

- Calculation of the time, using the altitude of the Sun. Especially used for estimating the exact prayers time.

- Determining the qibla direction using first mid-afternoon line.

- Calculating declination of the Sun.

- Estimating an hour angle of any star by using its altitude.

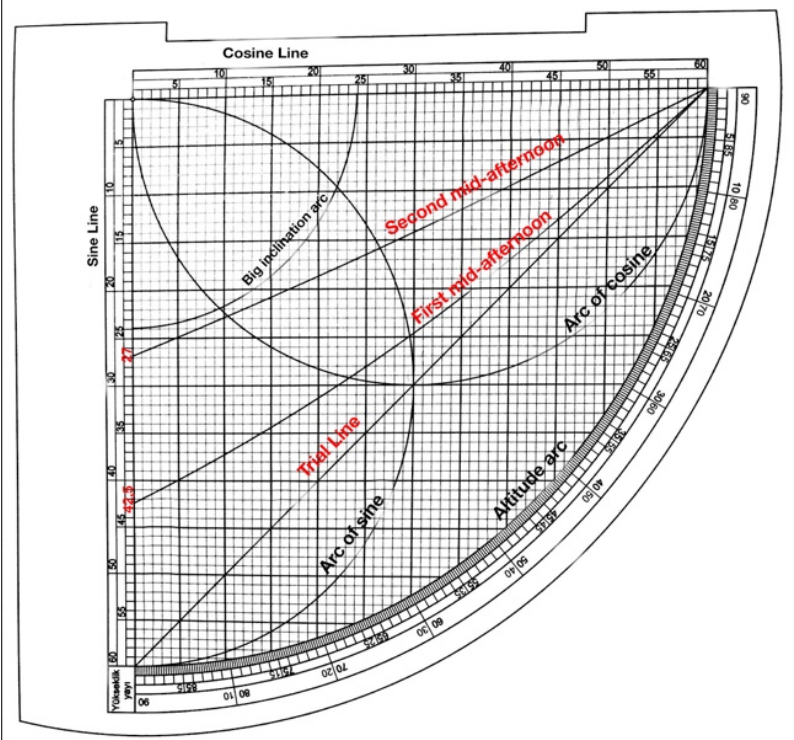

Figure 17. Face of the sine quadrant. 
- Solving the problems that have solutions based on geometric proportion.

- When there are given 2 different locations with different latitudes, if one of these locations altitude and azimuth was known, one can calculate the other's values by the help of this device.

- Calculating square root and cube root of any number.

- Calculating square and cube of any number.

- Multiplication and division of any two numbers.

- Determining the sine, cosine, tangent, cotangent and sehm ${ }^{3}$ values.

- Measuring height and depth of the outlying lengths (such as height of mountains or depth of wells or width of streams) (Figure 18 \& Figure 19) (Demir, 1992: pp. 29-52).

This portable device was especially popular among the Ottomans until the 20th century. They were using that instead of a pocket clock, since it was easy to use and carry and also was cheaper than a pocket clock.

Sector (Pergar-1 nisbe) is another instrument widely used in the military academies. This mathematical instrument was used in order to find the proportions between quantities of the same kind; as between the line and another, between the superficies and another, between the solid and another (Stone, 1723: p. 46). This device was formed by clinching two equal rulers from their edges by a rivet. The centre of this rivet is also the centre of the sector. This rivet renders the instrument's motion uniform. In order to use the sector, one must also have a divider or ruler (see Figure 20). Thus, necessary length gaps between the arms can be measured without any error and put in the related proportional equation.

The calculation capacity of the sector depends on the scales embedded on the arms of this instrument. These embedded scales are commonly drawn upon the faces as fix kind of lines. These are line of equal parts, line of planes, line of polygons on one side, line of chords, line of solids, and the line of metals on the

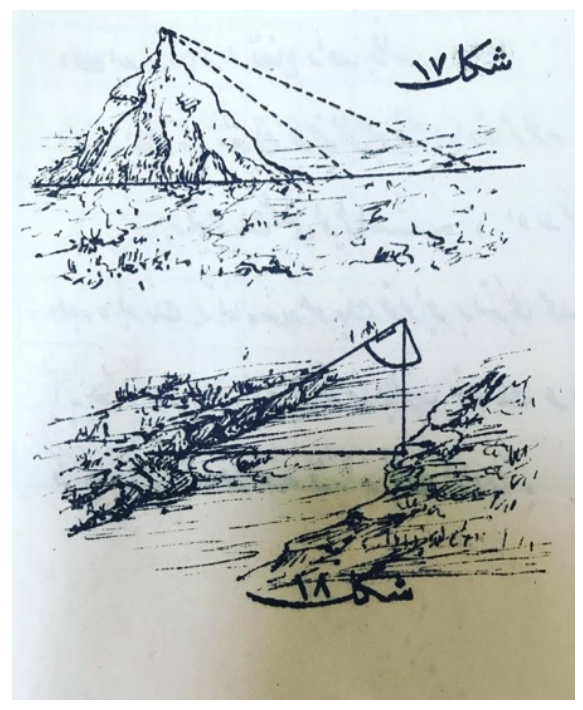

Figure 18. Measuring height of a mountain and width of stream by using sine quadrant (Gökmen, 1948).

${ }^{3} \operatorname{Sehm}(a)=60-\cos (a)$. 


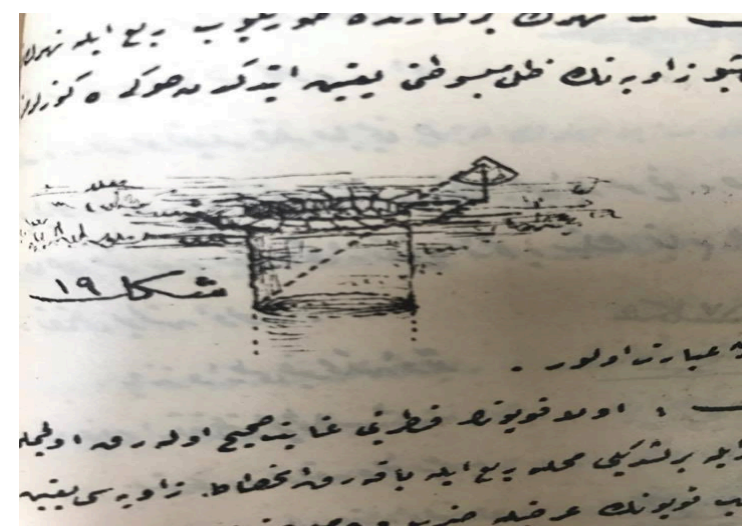

Figure 19. Measuring depth of a well by using sine quadrant (Gökmen, 1948).

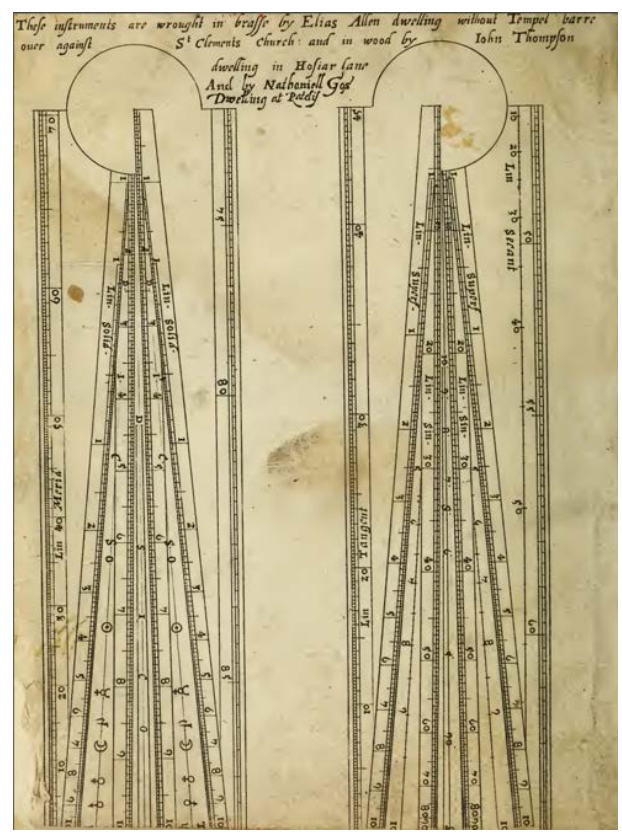

Figure 20. Sector with additional trigonometric and meridian lines from the E. Gunter's book's introduction page. This page hasn't got any page number assigned (Gunter, 1624).

other side (Stone, 1723: p. 46). The number of these scales may differ by the kind of sector. For instance, Edmund Gunter's (1581-1626) sector has additional lines such as meridian lines and trigonometric scales (sine, tangent, secant) (Gunter, 1624).

Sector was used mainly for military or navigational needs among Ottomans. It was allowing the easy and precise calculations for the soldiers in the battlefield without requiring any particular talents in mathematics (Figure 21).

The Ottomans named sector as pergar-1 nisbe, which is a literal translation of proportional compass. This translation is coming from an alternative name for sector in French, compass de proportium. The Ottomans translated nine different treatises related to this instrument in the second half of the 18th century and each of those treatises has the common main source which was Nicholas Bion's (1652-1733) Traité de la construction et des principaux usages des instruments de mathématiques (Polat, 2016). That makes a total sense, because during the 


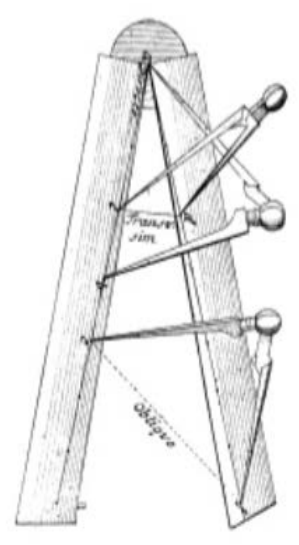

Figure 21. Sector (Leupold 248).

modernization period, the reform (nizâm-1 cedid) planers modelled France especially for teaching the applied disciplines. For the theoretical curriculum, their model was Austria's Militär Akademie and Akademie Enginieur. But why they didn't pick more updated source is a mystery. After all, the first publishing of Bion's book was at 1709. Chief instructor Ishaq Efendi also mentions this instrument in his Mecmûa-i Ulûm-i Riyaziye Vol. 1, p. 450 (see Figure 22 \& Figure 23) in the 19th century. There is at least one century between these dates.

Sector can be used in many calculations depending the scales it has, as it is mentioned above. Here are some elementary problems that can be solved by the help of it. One can easily see that most of these operations are common with the rubû̉ el-müceyyeb (sine quadrant) mentioned above.

- All kinds of problems which can be solved by the ratio and proportion.

- Calculating square root and cube root of any number.

- Calculating square and cube of any number.

- Multiplication and division of any two numbers.

Example: In order to divide 100 by 3, we should pick two arbitrary numbers such as $k$ and $3 k$. Assume that we have picked $k=7$ so $3 k=21$. In this case we should open the base of the sector 21 units and mark the place on the arms which has 7 units gap in between the arms (Figure 24). Then we may convert it in to a triangle $\mathrm{ACD}$, such as $|\mathrm{AC}|=|\mathrm{AD}|=100,|\mathrm{CD}|=21$ and $|\mathrm{BE}|=7$ while $|\mathrm{AE}|=|\mathrm{AB}|=x$.

From that one can easily measure the value of $|\mathrm{AE}|=x$, Equation (1). The crosscheck of that measuring is simply

$$
\begin{aligned}
& \frac{|\mathrm{AE}|}{|100|}=\frac{|7|}{|21|} \\
& |x|=33 . \overline{3}
\end{aligned}
$$

By finding $X$, we have found the division of 100 to 3 .

\section{Conclusion}

In the Ottoman Empire, mathematics and geometry were a part of education 


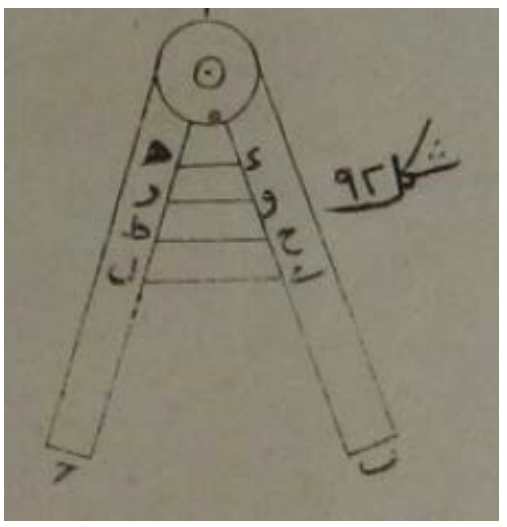

Figure 22. Sector sketch in Mecmûa-i Ulûm-i Riyaziye Vol.1. p.6 of his figures.

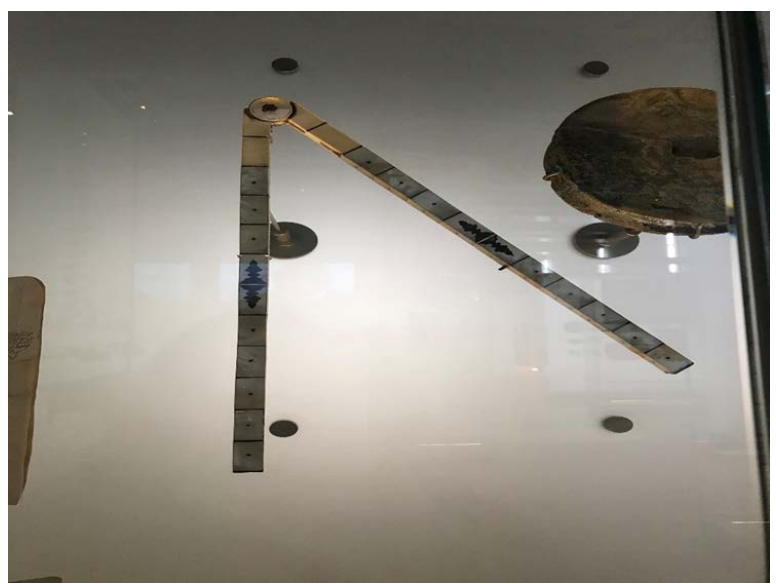

Figure 23. Ottoman proportional compass 19th c. (Musee IMA inv.)

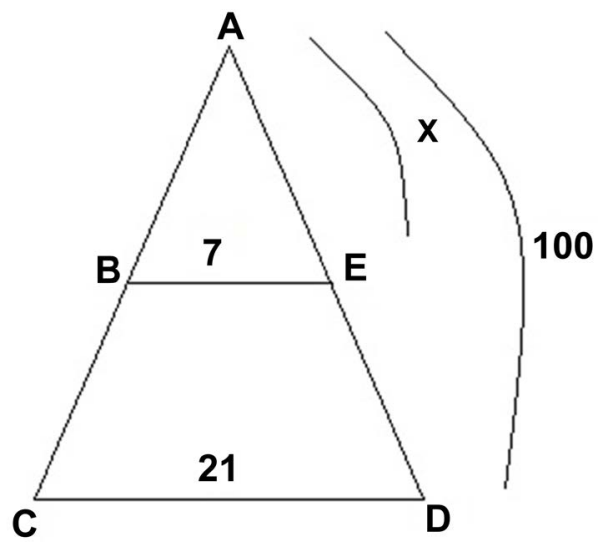

Figure 24. Solution of the problem dividing 100 by 3 with the help of the sector.

system by means of the needs of the empire. During the Classical period which was 14 - mid 18th centuries, they followed the archaic methods in science that they took over from the Medieval Islamic world. That was enough for them in order to compensate their religious needs as well as daily needs. By following this civilization's legacy strictly as if, it is a kind of dogmatic religion, they almost finished all kinds of scientific and technological activities around the 


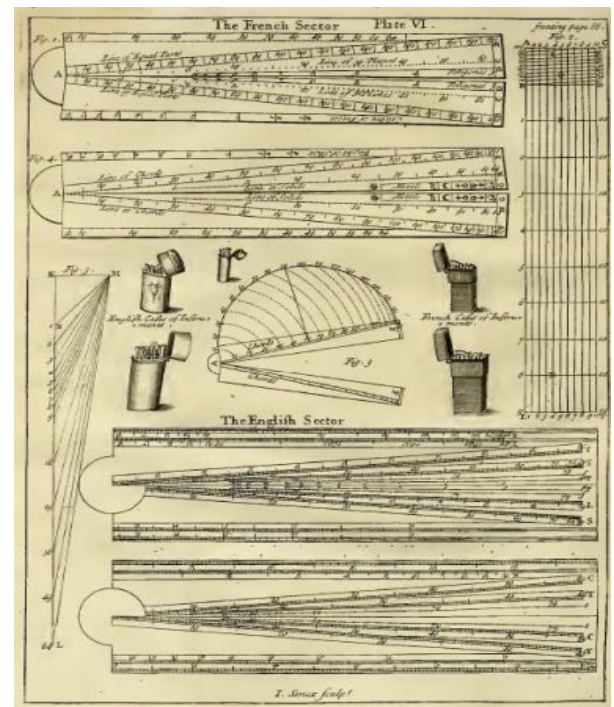

Figure 25. French Sector and English Sector from the book of E. Stone p. 69 which is a revised English translation of Nicholas Bion's Traité de la construction et des principaux usages des instruments de mathématiques.

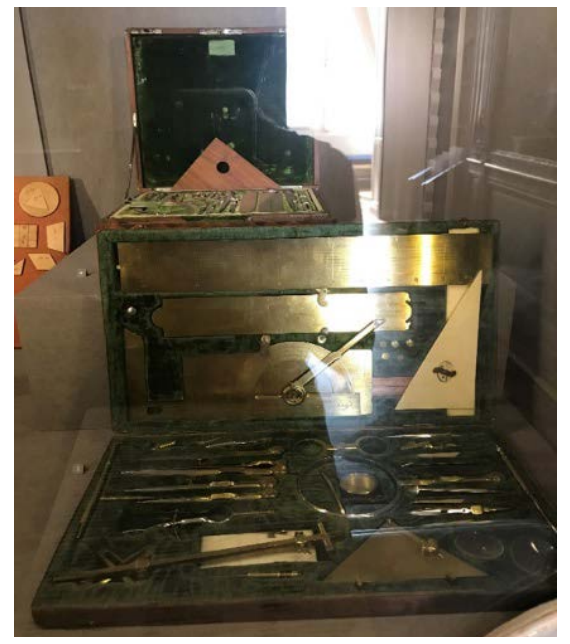

Figure 26. French, Engineer's Toolbox (Musée du Louvre) ${ }^{4}$.

empire. The science that they were practicing was nothing but an infinite reputation. They were still teaching the works of Islamic scholars' which based on the works of the ancient Greek scholars. Yet the time imposed itself on the Ottomans and they realized that they fell behind of the technology of their Western rivals in the battlefield. Since the Ottomans were a military oriented community, once they realized that fact, they urgently made some reforms in the military and in order to train elite cadets and transform the Western knowledge in the empire, they established Navy Military Engineering Academy and Army Military Engineering Academy. However fully functioning of the curriculum by means of reformed education was only possible in the second half of the 19th century because of the traditional teachers who were supporter of the scholastic madrassa ${ }^{4}$ This picture is taken by the author herself from the Musée du Louvre (Figure 25 \& Figure 26). 
education. These engineering schools were in the centre of the conflicts between traditionalists and secularists. Nevertheless, the conflicts between them could not stop the modernization period and the students who graduated from these academies constituted a pave to modern Turkey.

In this article, the commonly used mathematical instruments among the Ottoman Empire have been examined and the obscure Ottoman terminology about the name of these mathematical instruments tried to be revealed. The author examined that by dividing the subject in two periods and pointed out that the instruments which were commonly used in the classical period are the instruments inherited from Medieval Islamic World. In the third chapter, the author also examined the instruments which were used in military academies in modernization period. We saw that the primary objective of these mathematical instruments was the military, not an intellectual interest to the theoretical sciences in the modernization period. That once more proves us the pragmatic nature of the Ottomans through sciences. The main problem while examining these inventory lists was the nomenclature of these instruments. There was not any visual document such as painting or a photograph in the original lists and the names were verbal sketches of these instruments, which makes our best bet in order to identify these instruments was to guess these devices by using the dictionaries and military museums' catalogues as well as the old Ottoman military school textbooks. For that Ishaq Efendi's compendium vol. 1 and 2 were really useful sources. According to that, this article can be considered as a terminology introduction trial for the mathematical instruments of the Ottomans. The author believes more results can be obtained by examining the above instruments one by one in the future studies.

\section{Conflicts of Interest}

The author declares no conflicts of interest regarding the publication of this paper.

\section{References}

Acar, Ş., Bir, A., \& Kaçar, M. (2014). Rubu Tahtası Yapım Klavuzu (Rubu Dâirenin Esâsı ve Usûl-i Tersimi). Istanbul: Ofset Yapımevi Yayınları.

Adıvar, A. (1970). Osmanlı Türklerinde İlim. Istanbul: Remzi Kitapevi.

Beydilli, K. (1995). Türk Bilim ve Matbaacılık Tarihinde Mühendishane ve Mühendishane Matbaası ve Kütüphanesi (pp. 375-409, 1776-1826). Istanbul: Eren Yayıncılık.

Demir, R. (1992). Eski Bir Hesap Aleti: Rub'u'l-Müceyyeb ve Takîyuddîn ibn Ma'rûfun Rub'u'l-Müceyyeble Yapılan İslemler Manzumesi Adlı Risalesi: Essay on Bilim ve Felsefe Metinleri 1 (pp. 29-52). Ankara: Öncü Kitap.

Efendi, I. (1257). Mecmûa-i Ulûm-i Riyâziye, Vol.1, 2. Cairo: Bulak Matbaası.

Gökmen, F. (1948). Rubu Tahtası, Nazariyatı ve Tersimi. Istanbul: Milli Eğitim Basımevi.

Gunter, E. (1624). The Description and Use of the Sector. London: Willia Jones.

Polat, A. (2016). Treatises on Pergâr-1 nisbe (Sector) in the Manuscript Collections of Turkey. XXVth Scientific Instrument Symposium: Instruments between East and West, 
Istanbul.

Sezgin, F. (2010). Science and Technology in Islam (Vol 3, p. 77). Publications of the Institute for the History of Arabic-Islamic Science, Frankfurt am Main.

Stone, E. (1723). The Construction and Principal Uses of Mathematical Instruments; Translated from the French of M. Bion Chief Instrument-Maker to the French King, H. W for J. Senex and W. Taylor, London.

Unat, Y. (2001). Seyyid Ali Paşa, Miratül-Alem (Evrenin Aynası), Ali Kuşçủ nun Feythiyye Adlı Eserinin Çevirisi. Ankara: Kültür Bakanlığı Yayınları.

Ziya, A. (1338). Rubu Dairenin Suret-i Istimali. Istanbul: Kandilli Boğaziçi. 